\title{
Congressional Caucuses and Congressional Committees: A Commentary on Vega
}

\author{
Thomas Longoria, Jr., Texas A\&M University
}

This comment on Vega's article, "Congressional Informal Groups as Representative Responsiveness," discusses where Vega's work fits into the congressional caucus literature, and suggests directions for future research on such caucuses.

Vega's work is motivated by an important theory that guides sound empirical analysis. The study is an important break from earlier work because of his use of representation theory to develop the representative responsiveness framework. Outlining the different strategies used by congressional caucuses to accomplish representational goals expands our understanding of congressional caucuses considerably. The case-study analysis is especially valuable and supports the factor analysis findings.

Vega points out the major shortcoming of research on congressional caucuses when he notes that "students of congressional caucuses remain uncertain whether to treat these caucuses as a sideshow or as something more important" (Vega 1993, 356). Toward this end, Vega attempts to correct the "tendency to treat congressional groups homogeneously within broad categoric types" and demonstrates the multidimensionality of congressional caucuses. Vega portrays congressional caucuses as "dynamic, shifting their roles and activities and responding to their environment," and concludes that they have "become integrated into the general structure and function of the legislative process" (Vega 1993, 363, 370).

However, the data marshaled by Vega do not necessarily support the argument that caucuses are an important part of congressional politics and policymaking. First, there are no direct measures of caucus activity and response. Second, because Vega's analysis is cross-sectional, conclusions suggesting a dynamic relationship in caucus interactions with the environment are not possible. Just because groups internal to congress exist and are varied does not mean that they necessarily are important. Similarly, just

THOMAS LONGORIA, JR. is ABD at Texas A\&M University.

The American Review of Politics, Vol. 14, Autumn, 1993: 381-386

(C)1993 The American Review of Politics 
because leaders and paid staff of congressional caucuses say that caucuses are active and successful does not mean that such groups indeed are active and successful. The remainder of this essay will consider two major methodological problems with the congressional caucus literature - the use of elite interviews and survey research - and will suggest how Vega's work fruitfully can be used to motivate future research on congressional caucuses.

\section{Categorizing Congressional Caucuses}

A substantial portion of research on congressional caucuses focuses on the different types that exist, their emergence in American politics, and the various strategies for representation and agenda-setting that are available to them (Vega 1993; Hammond, Mulhollan, and Stevens 1985; Loomis 1981; Barnett 1977). In previous research, several aspects of congressional caucuses have been quantified and analyzed. Despite the progress made describing congressional caucuses, there has been little progress in determining their impact upon congressional behavior and policy making. In other words, much work has been done to specify independent variables, but little has been done to specify dependent variables. Without more rigorous models, research cannot establish if congressional caucuses are more than "just a sideshow."

Consider the present study (Vega 1993) and a recent study (Hammond et al. 1985) of congressional caucuses. Each relies on a different framework: Vega examines representation theory and Hammond et al. examine agenda setting. Each demonstrates that congressional caucuses are diverse and that these differences lead to different strategies for representative responsiveness and agenda setting. Each also concludes that caucuses are active and successful at representing interests or affecting the governmental and/or public agenda.

However, each study also uses survey research and interviews of caucus directors, which probably overestimates the true level of caucus activity because of response bias. Few caucus directors are likely to admit that they are doing little to advance the goals of their organization. It is not so much whether response bias is affecting the findings, but to what degree. Research involving surveys must search for data and methods that can enhance external validity.

The remainder of this commentary examines the conventional wisdom that different types of congressional caucuses use different strategies for accomplishing goals and are active participants in congressional politics. 


\section{Congressional Caucuses in Congressional Committees}

Congressional caucuses have been examined using case-study (Dilger 1982) and roll call voting (Levy and Stoudinger 1976) analysis. These studies rightly have asked whether caucuses make a difference in policy making and congressional behavior. Relevant impacts include the passage of legislation that a caucus actively supports, and the propensity of legislators to rely on a caucus' position as a voting cue. Vega, with his emphasis on other representational roles such as agenda setting and committee activity, brings the literature on caucuses in line with congressional scholarship that emphasizes committee-based activity more than roll call votes and the passage of legislation (e.g., Hall and Wayman 1990).

If caucuses are attempting to represent constituencies and place issues on the agenda, one manifestation of this initiative would be higher levels of activity in committee hearings, such as testifying on behalf of a caucus. ${ }^{1}$ Given the variety of different activities that congressional caucuses undertake (Hammond et al. 1985; Vega 1993), only examining hearing activity underestimates the total level of caucus activity. However, the committee activity variable used here focuses on actual participation in congressional committees, rather than self-reported activity. Following Vega's findings, the level of congressional caucus activity should vary according to the size and type of caucus (Hypothesis 1).

Congressional caucus activity is operationalized as the number of times that a member of a caucus testifies on behalf of that caucus. The level of caucus activity is measured using Congressional Information Service Abstracts (CIS, annual). This variable is collected by searching for each time that the name of a congressional caucus appears as the reported affiliation for a member of Congress who appears before a committee. Each instance of caucus testimony is weighted equally, and the number of times that a member of a caucus testified each year from 1970 to 1992 is summed as the measure of cacus activity for all caucuses and individual caucuses. ${ }^{2}$

From 1970 to 1992, 251 congressional committee hearings had at least one member of congress testify representing a congressional caucus. There is not an equal distribution of activity over time. Figure 1 indicates that there was steady growth in caucus activity in the 1970s, a peak in activity during the early to mid-1980s, and an eventual drop back to pre-1980 levels.

Hypothesis 1, that caucuses should vary across type, is examined by comparing the levels of caucus activity from 1970 to 1992 for 16 selected caucuses of various types, e.g., ethnic/gender, business/industry, and regional. Relatively low levels of committee-focused activity were found for 
384 | Thomas Longoria, Jr.

Figure 1. Number of Hearings by Year

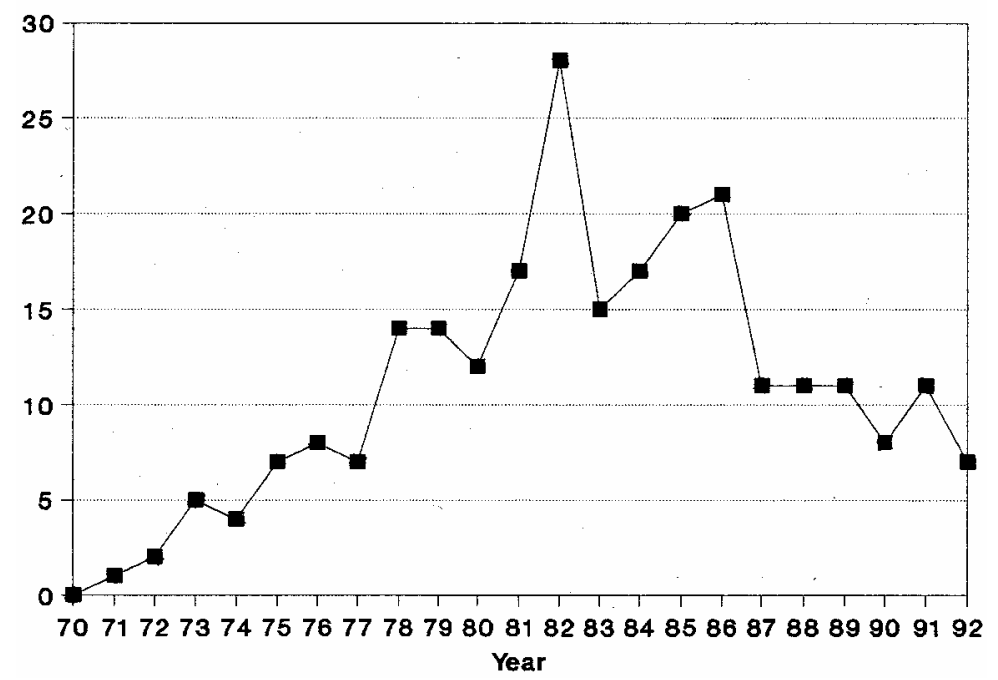

Table 1. Congressional Committee Hearing Participation by 16 Selected Congressional Caucuses, 1970-1992*

\begin{tabular}{lc}
\hline Caucus & $\begin{array}{c}\text { Number of } \\
\text { Hearings }\end{array}$ \\
\hline Congressional Black Caucus & 68 \\
Northeast-Midwest Congressional Coalition & 21 \\
Congressional Rural Caucus & 21 \\
Congressional Hispanic Caucus & 19 \\
Congressional Steel Caucus & 14 \\
Congressional Caucus for Women's Issues & 5 \\
Textile Caucus & 2 \\
Ad Hoc Congressional Comm. for Irish Affairs & 0 \\
Congressional Suburban Caucus & 0 \\
Conference of Great Lakes Congressmen & 0 \\
Blue Collar Caucus & 0 \\
New England Congressional Caucus & 0 \\
Congressional Ad Hoc Group on South Africa & 0 \\
Metropolitan Area Caucus & 0 \\
Congressional Port Caucus & 0 \\
Congressional Shipbuilding Coalition & 0 \\
Total & 150 \\
\hline
\end{tabular}


a majority of the caucuses examined. This finding should be expected, given the scarcity of instances in which any caucus was represented at committee hearings (see Figure 1). Table 1 reports the number of times that a member of Congress testified on behalf of the 16 selected congressional caucuses.

Two of the caucuses most active in legislative terms, the Congressional Black Caucus (CBC) and the Congressional Hispanic Caucus (CHC), are ethnic/gender-based caucuses. In fact, in many years the Black Caucus accounts for about half the total number of times that a member of Congress testified as a representative of a caucus. Region-based caucuses - such as the Northeast-Midwest Congressional Coalition (NEMWCC) and the Congressional Rural Caucus (CRC) - and industry caucuses such as the Congressional Steel Caucus also are active, but to a lesser degree. However, there is not strong support for Hypothesis 1 because for every ethnic/genderbased, region-based, or industry-based caucus that is active there is another that is relatively inactive, such as the Congressional Caucus for Women's Issues, the Conference of Great Lakes Congressmen, and the Congressional Shipbuilding Coalition (see Table 1).

The above-mentioned four most active congressional caucuses - the $\mathrm{CBC}, \mathrm{CHC}$, NEMWCC, and CRC-bear closer examination. Each has a high level of activity in different years (see Figure 2). The NEMWCC had the highest level of activity in 1980, during which it was concerned with economic growth, transportation issues, and intergovernmental grant funding criteria. The CBC's activity peaked in 1982, when its members testified in

Figure 2. Number of Hearings for Selected Caucuses

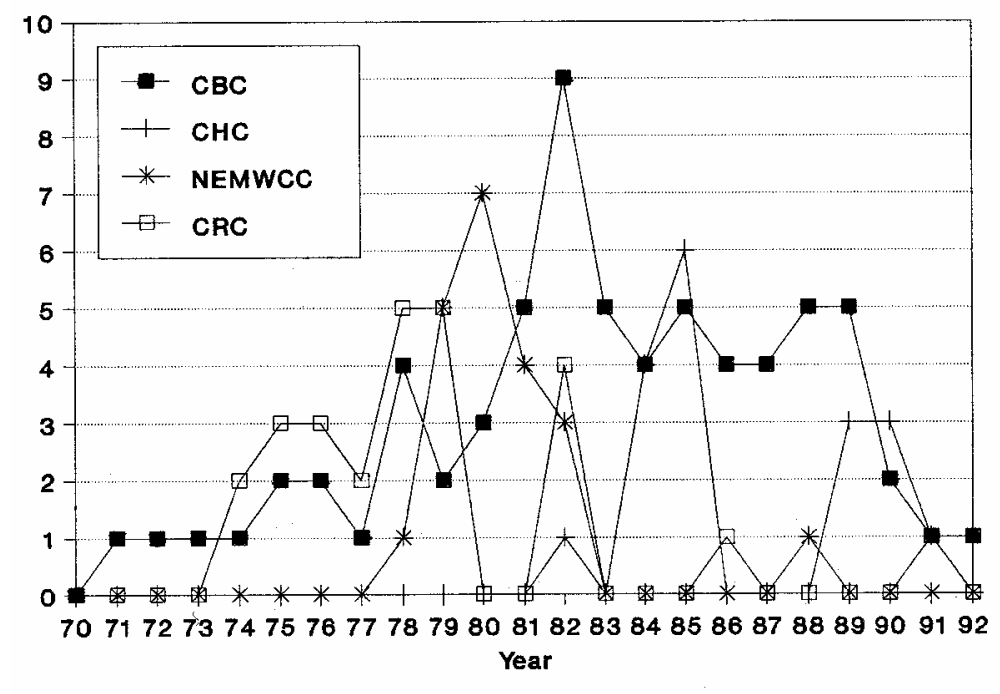


committee hearings about (1) the impact of Reagan's proposed budget cuts in social programs, and (2) extension of the Voting Rights Act of 1965. The CHC peaked in 1985, when the key issues were immigration reform and the proposed English Language Amendment.

Caucus activity increases, then, when there is a specific issue that is of intense interest to caucus members and their constituents. Thus, there is support for Vega's assertion that caucuses are dynamic and responsive to changes in the decision-making environment. However, because caucuses are only briefly active, the extent to which they are becoming institutionalized as part of the congressional policy-making system is not clear.

\section{Discussion}

Many questions about congressional caucuses remain. While many agree that congressional caucuses play a role in the policy making process, there is no consensus about the scope of that role. Future analyses should use a combination of survey interviews, case-study analysis, and objective timeseries data analysis to produce more comprehensive models and a better understanding of the role of caucuses in congressional politics.

\section{NOTES}

\footnotetext{
${ }^{1}$ Other aspects of caucus activity discussed by Vega (1993), e.g., 'Dear Colleague' letters and meetings with party leaders, are harder to quantify and should be examined in future research. The analysis presented below is used for illustrative purposes.

${ }^{2}$ The data for 1992 run through September.
}

\section{REFERENCES}

Barnett, Marguerite Ross. 1977. The Congressional Black Caucus: Symbol, Myth, and Reality. The Black Scholar 8: 17-26.

Dilger, Robert Jay. 1982. The Sunbelt/Snowbelt Controversy: The War Over Federal Funds. New York: New York University Press.

Hall, Richard L. and Frank Wayman. 1990. Buying Time: Moneyed Interests and the Mobilization of Bias in Congressional Committees. American Political Science Review 84: 797-820.

Hammond, Susan Webb, Daniel P. Mulhollan, and Arthur G. Stevens, Jr. 1985. Informal Congressional Caucuses and Agenda Setting. Western Political Quarterly 38: 583-605.

Levy, Arthur B. and Susan Stoudinger. 1976. Sources of Voting Cues for the Congressional Black Caucus. Journal of Black Studies 7: 29-45.

Loomis, Burdett A. 1981. Congressional Caucuses and the Politics of Representation. In Lawrence C. Dodd and Bruce I. Oppenheimer, eds., Congress Reconsidered. Washington, DC: Congressional Quarterly Press.

Vega, Arturo. 1993. Congressional Informal Groups as Representative Responsiveness. American Review of Politics 14: 355-373. 